\title{
A Women-Only Leadership Development Program: Facilitating Access to Authority for Women in Swedish Higher Education?
}

\author{
Helen Peterson \\ Department of Sociology and Work Science, University of Gothenburg, SE-405 30 Gothenburg, Sweden; \\ helen.peterson@gu.se
}

Received: 28 February 2019; Accepted: 29 April 2019; Published: 2 May 2019

\begin{abstract}
This article explores a national women-only leadership development program in Swedish higher education, the so-called IDAS program (an acronym for Identity, Development, Advancement, Support). IDAS encouraged and supported women academics to pursue leadership/administrative careers in higher education and was a unique intervention, aiming to increase the number of women Rectors. By drawing on interviews with some of the women who participated in the IDAS program and subsequently became Rectors, the article provides a valuable case study over best practices to increase women senior leaders in higher education. Notwithstanding the success of the leadership program, the article also deals with resistance and criticism linked to equal opportunity initiatives such as this. The article analyzes the criticism voiced by the women interviewed and suggests that it can be understood in relation to different conceptions of gender and gender (in)equality.
\end{abstract}

Keywords: women-only; leadership development program; higher education; Sweden; Rectors

\section{Introduction}

The position as head of university (referred to as Vice-Chancellor, President, or Rector in different countries) has traditionally, and worldwide, been male-dominated. This male domination reflects gendered power relations and hegemonic masculine leadership models within the higher education sector. Notwithstanding, the proportion of women Rectors in several European countries, among them Sweden, has been increasing (European Commission 2019). In 2015, 59 per cent of the largest higher education institutions in Sweden had a woman in a Rector position (Peterson 2018). The article investigates one possible contributing factor to this increase and sets out to provide a documentation of a success story of "women accessing authority" (Morley 2013, p. 126) in higher education. The overall aim of the article is to discuss if, how, and to what extent a women-only leadership development program; the IDAS program (an acronym for Identity, Development, Advancement, Support), contributed to the increase of women Rectors in Swedish higher education.

The article draws on interviews with 15 women who held Rectors positions at different Swedish higher education institutions (universities and university colleges) between 2010 and 2019. The analysis of the interviews focuses on their experiences of, and attitudes towards IDAS, a national women-only leadership development program that was set up to support women and increase the proportion of women senior academic leaders. The more specific aim of this article is to investigate how these women Rectors made sense of this initiative. The article highlights how, and to what extent, the women interviewed perceived that the IDAS program had supported them in their career and if and how they had benefitted from the program. The analysis also draws attention to the criticism some of the women voiced. Theories about interpretative frames are used to understand this criticism. 


\section{Previous Research}

There has been a growing interest in implementing efforts to close the gender gap on decision-making positions and in governing bodies in higher education during the last decades (cf. Doherty and Manfredi 2010). Jennifer De Vries, in her doctoral thesis, describes women-only leadership development programs targeting gender inequality in leadership positions as a "tried and true gender equity strategy" (De Vries 2010, p. iii). Women-only leadership development programs are frequently implemented to encourage women's participation in management positions and to increase women in senior leadership positions such as Rector and Dean (see, e.g., Barnard et al. 2016; Dahlerup 2010; Madsen et al. 2012; SOU 2011). The HERS Institute (Higher Education Resource Services) has provided leadership programs for women at higher education institutions in the USA since 1976 and is one of the most successful and longstanding examples of this strategy (White 2012). There are also examples of leadership development programs targeting specifically women in the male-dominated STEMM fields (science, technology, engineering, mathematics, and medicine) (Magrane and Morahan 2016). Bonebright, Cottledge, and Lonnquist (Bonebright et al. 2012) describe the guiding principles used to build women's leadership programs at the University of Minnesota and emphasize the importance of honoring women's leadership styles, building collaborations and networks, and leading for equity and systems change. Further, O'Meara and Stromquist (2015) emphasize networks as an important intervention within the ADVANCE programs in the USA and how these improve the recruitment, retention, and advancement of women. The evaluations and reports from these initiatives highlight the positive impact they can have in advancing women to senior leadership positions in higher education (cf. Corby 2014).

Initiatives such as women-only leadership development programs have, however, also received criticism from practitioners, stakeholders, researchers, and feminists. The limited potential of these programs to actually challenge and transform the gendered nature of organizations has been pointed out (De Vries 2010). Instead, women-only leadership development programs tend to, inadvertently, blame women for gender inequality problems or define gender inequality as a "women's problem" without organizational cultures being challenged (cf. Burkinshaw 2015). Ely, Ibarra, and Kolb (Ely et al. 2011, p. 475) raise their concern about leadership education for women. They argue that one of the reasons why leadership development programs for women fail is that: "Practitioners and educators lack a coherent, theoretically based, and actionable framework for designing and delivering leadership programs for women." One of the failures of previous women-only leadership development programs, according to the authors, has been their focus on emphasizing that women must be taught the skills needed to be successful, skills already acquired by men: "Leadership development programs that teach women to act like men to get ahead are misguided and likely to misguide women leaders" (Ely et al. 2011, p. 488). Instead, the authors highlight certain aspects as important when designing women-only leadership development programs, for example, how professional networks can contribute to build and deepen expertise, power, and credibility as a leader (Ely et al. 2011).

Women-only initiatives are also commonly criticized as they raise concerns about quality, excellence, and meritocracy in higher education and about stigmatizing women who participate in them (Van den Brink and Stobbe 2014). Resistance towards women-only programs is sometimes also voiced by women, who: "do not want to be identified as whiners and losers; they want to be seen as making it on the basis of their own capacities" (Acker 2000, p. 631). Van den Brink and Stobbe (2014) refer to this with the expression "support paradox", meaning that women are viewed as getting "helped" by these initiatives without it being acknowledged that many men also receive help in their careers by informal networks, mentors, and sponsors.

Their popularity, in combination with the proposed limited change potential, however, make women-only leadership development programs important to investigate. 


\section{Theoretical Framework}

The theoretical framework of the article is constituted by feminist theory, and more specifically critical feminist organization theory. This is a theoretical framework that provides us with useful theoretical tools to investigate and explain how gender continues to inform organizational processes, practices, and structures (Acker 1990, 2006, 2012). Fundamental to feminist theories are definitions and understandings of the nature of gender (in)equalities as organizational phenomena. Ely and Meyerson (2000b) and Meyerson and Kolb (2000) developed a typology over four different approaches, or interpretative "frames", to gender and organizational change. The different approaches are based on different conceptions of gender, different visions of what gender equality is, and different ideas about what strategies should be used for achieving that vision. The authors describe the three first as "traditional approaches" and the fourth as an "alternative", more progressive.

The first of these approaches is named "fix the woman" (Ely and Meyerson 2000b) or "equip the woman" (Meyerson and Kolb 2000) and has been the most popular and common. This approach targets organizational inequalities through an understanding of socialized differences between women and men. It is based on political thoughts on liberal individualism and posits that women are actually less well-equipped than men to compete for positions and take on, for example, leadership roles. The actions developed within this kind of theoretical framework only target women and intend to empower women and strengthen their position in the organization by equipping them with appropriate skills, competence, and networks. Women are thus supposed to learn how to compete with men and "play the game better" (Ely and Meyerson 2000b). This approach has been efficient, for example, in increasing eligible women candidates to top positions. The approach, however, is limited as it does not challenge existing structures and the system that benefits men. It also tends to blame women for gender inequality in organizations (Meyerson and Kolb 2000). The glass ceiling thus remains.

The second approach is the "value the feminine" (Ely and Meyerson 2000b) or "value difference" (Meyerson and Kolb 2000) approach. While this approach also defines gender in terms of socialized differences just as the first approach, it instead emphasizes the need to recognize and value women's contribution. With this approach, the problem with gender inequality is attributed to the lack of rewards for specifically women's skills. The goal with interventions within this approach is thus often to "give voice to women's perspective" (Ely and Meyerson 2000b, p. 109) and to celebrate and reward what are seen as typical feminine behaviors and attributes: Listening, collaborating, nurturing. The approach to increased gender equality, within this frame, is sometimes expressed in terms of a 'business case' for gender equality. This approach is limited because it can reinforce existing stereotypes about women as "different". It also fails to recognize oppression and diversity within the group of women and does not challenge the organizational processes that produce differences.

The third approach is the "create equal opportunity" approach (Ely and Meyerson 2000b). It identifies the problem with organizational power structures that limit women's access to valuable resources and restrain their career opportunities. The approach specifically recognizes how men's greater professional networks provide them with advantages while women higher up in the organizational hierarchy become isolated tokens. Interventions within this frame therefore focus on challenging these structural barriers by creating new systems and policies for recruiting, retaining, and advancing women. Affirmative actions are implemented, more transparent promotion practices employed, and formal mentoring programs developed. Another special focus is on creating work-life balance. Policy changes within this approach can benefit women's career, especially in entry and middle levels. This approach, however, also has limitations. There is a danger that, for example, work-life balance is understood as a "women's problem" without challenging organizational cultures. Although a flexible work policy might be in place, people might not take advantage of it, and those who do might see detrimental effects on their career opportunities. The interventions, thus, do not manage to disrupt: "the pervasive and deeply entrenched imbalance of power in the social relations between men and women" (Ely and Meyerson 2000b, p. 113). 
Ely and Meyerson (2000b) describe the fourth approach as a "post equity" approach that involves resisting and revising the dominant discourse (revision work culture). While the first three frames have a common focus on women, the fourth frame shifts this focus, from women to structural and organizational aspects that reproduce gender inequity (Ely and Meyerson 2000a). This approach draws on a theoretical framework that identifies how supposedly gender-neutral social practices reproduce a system of oppressive relations in organizations that privileges men. The limitation of this fourth approach is the organizational resistance when such deep change of organizational culture is the goal. According to Meyerson and Kolb (2000), this is an approach with a more complex and comprehensive perspective on gender, understanding organizations as inherently gendered. The goal of interventions within this approach is for organizational members to challenge and transform the sense of what it means to be male or female, masculine or feminine (Ely and Meyerson 2000a).

\section{Materials and Methods}

This article draws on interviews with 15 women who, at the time of the interview, held the position as Rector at a Swedish higher education institution. The majority of the interviews (11 of 15) were performed between 2015 and 2016, as part of a research project on leadership ideals in Swedish higher education. In addition to the 11 interviews performed between 2015 and 2016, four other interviews with women Rectors are included. They were performed as part of a pilot-study in 2010 (cf. Peterson 2010, 2015, 2016). The purpose of the two studies was similar: To investigate women academics' experiences of leadership. The women were not asked to participate in the study because they had experiences of IDAS but because of the academic leadership position they held. Whether or not they had participated in IDAS or whether or not they approved or disapproved of women-only leadership development programs was not a criterion for selection.

Twelve of the 15 women interviewed were professors. They were between 52 and 67 years old, and they had between 20 and 30 years of experience of working as researchers, lecturers, administrators, and managers in the Swedish academia. They came from fifteen different universities and university colleges, situated in different parts of Sweden: North, south, east and west. Some of these higher-education institutions were large universities with hundreds of years of traditions, while others were smaller, more recently established university colleges. All participants in the study were promised anonymity, and no names of participants or higher education institutions will be revealed. The study was conducted in keeping with research ethical guidelines and principles at the University of Gothenburg and the Swedish Research Council (Swedish Research Council 2017).

All of the interviews were conducted in Swedish by the author and lasted between 40 and 70 minutes. The interviews were semistructured, encouraging the women to reflect on their experiences from being a senior academic leader and share them in an open manner (Scheibelhofer 2007). The semistructured character enabled attention to be paid to individual differences in the women's unique experiences. This methodology followed feminist principles about exploring women's lived experiences and privileging women's voices (Parr 2015).

A thematic interview guide was used, with approximately 20 questions focusing on gender and change in academia and encouraging the women to share their experiences of being a woman leader in higher education. The analysis in this article draws mainly on the experiences they shared as a response to two different questions; one of these questions asked them to tell about factors that had supported them in their individual career, while the other focused on how they would explain the increase of women Rectors in Swedish higher education and which factors they identified as important for this increase. In some interviews, the women referred to IDAS in their answers to both questions, in some interviews only in the answer to one of the questions. The interviews also included critical reflections regarding women's leadership development programs in general and IDAS as one example of such programs.

Although the pilot-study in 2010 and the main study in 2015-2016 had similar purposes and similar interview guides, it has to be acknowledged that the purpose of the pilot-study was to analyze 
the interviews as part of an evaluation effort of IDAS. The leadership development program was thus initially mentioned by the interviewer/author during these interviews with the women. The interview guide also included one explicit question about IDAS, encouraging the women to share their experiences of the program, in case they had any experience. In the later study, IDAS was not mentioned beforehand by the interviewer/author. When asked what they saw as the most important contributing factor to women's increase in the Rector position in Swedish higher education, more than half of the women interviewed instantly mentioned IDAS, sometimes without being able to identify any other factor. Even those who raised criticism towards IDAS mentioned the importance of the program. This was considered as a remarkable result and worth analyzing in more depth.

All interviews were fully and verbatim transcribed following guidelines about naturalness and authenticity (cf. McLellan et al. 2003). A conventional, qualitative content analysis was used, focusing on the meaning produced in the interviews (Elo et al. 2014; Krippendorff 2013). The analytical process started with the author reading the transcriptions carefully in order to identify salient issues and noting response patterns for each of the questions (Hsieh and Shannon 2005). A range of techniques such as coding, categorization, and theme formation was used in order to discover similarities and differences in perceptions and experiences (Ryan and Bernard 2003).

The analysis was inspired by a phenomenological and hermeneutical framework (cf. Seidman 1998; Smith et al. 1999) and guided by an interpretivist-theoretical tradition focusing the notions of self, self-concepts, identities, and meaning-making processes (Manning and Kunkel 2014). This is a framework which allows for an emphasis on the women's meaning-making. The analysis thus focused on discerning what the women themselves wanted to tell and to what they themselves ascribed value, meaning, and importance (cf. Smith et al. 1999).

\section{Background}

\subsection{Initiating and Establishing the Program}

This article focuses on a national leadership development program for women in Swedish higher education. The program was initiated by Ingegerd Palmér, who was the Rector at Luleå University of Technology (between 1994 and 2005) and at Mälardalen University College (2005-2011). Ingegerd Palmér has described that when she first became a Rector, every fifth Rector in Swedish higher education was a woman, but how she noted that women started to disappear from the position a couple of years later (Swedish Research Council 2006). This is also confirmed by the "dip" in statistics, showing how the proportion of women Rectors went from 31 per cent in 1995 to only 13 per cent in 2000 (Peterson 2017). According to Ingegerd Palmér, this worried her, and she turned to the Association of Swedish Higher Education (SUHF) to suggest that a leadership network for women should be established, a suggestion that immediately gained everybody's support (Swedish Research Council 2006).

As a result, a women-only leadership development program was launched in 1999. The program became known under the acronym IDAS, which stands for Identity, Development, Advancement and Support. The Association of Swedish Higher Education coordinated and funded the project, and the Rectors of the higher education institutions were responsible for the operation of IDAS. During the most active phase, between 2004 and 2007, the program received approximately SEK 23 million to fund a variety of initiatives and measures throughout the country. The program also received funding from the Development Council for the Government Sector from 2003 to 2007. The program continued until 2007, and Ingegerd Palmér remained the president of the program until then (Bergman 2013).

\subsection{Aim and Purpose of the Program}

The program was open to academic women with research and teaching positions, and the aim of the program was to increase the number of women in upper-level academic positions such as Dean, Pro-Dean, Rector, and Pro-Rector (Bergman 2013). The purpose was to encourage women academics to 
pursue a management career in higher education. It very explicitly encouraged women in the program to put themselves forward as candidates in elections for Rectors and Dean in Swedish higher education.

The inspiration for the Swedish IDAS program was the American network IDAS, created by the American university president Judith Sturnick (Blom 2010). While the US model was developed based on ideas about women's individual adjustment, the aim of the Swedish IDAS shifted slightly during the years. Agneta Blom, one of the operative directors of the program, explains: "These changes in perspective came about gradually and implied a focus shift from concern mainly for individuals to including the fundamental structures of academic leadership" (Blom 2010, p. 306).

\subsection{Activities within the Program}

In line with the acronym IDAS, the program focused on activities to identify women candidates, develop their skills, make it easier for women to advance, and to support them in academic leadership (Blom 2010). The IDAS model, adopted from the USA, had a pedagogic concept focused on promoting more applications by women candidates for Rector positions and preparing and training women for such positions through a variety of activities and measures (Blom 2010).

The program's main activities involved arranging thematically-oriented seminars about women and leadership. These competence-building seminars also created arenas for women academics to meet inspiring lecturers and successful role models (Bergman 2013). The program, however, also generated a large number of other activities, measures, courses, and subprojects. One of the most prominent functions of the program, in addition to the seminars, was the establishment of networks between women on local, regional, and national level, thus facilitating an exchange of information, knowledge, and competence between women who would not have met otherwise (Bergman 2013). Some of the IDAS networks also took the form of mentoring programs and then sometimes included men mentors. Men were also regularly invited as speakers at events (Blom 2010). A large number of different reports on academic leadership were produced within the program and were made available for download on the webpage of the program (Fahlgren et al. 2007; IDAS 2007a, 2007b; Ljung 2005; Marcusson 2007; Nydahl 2007).

\subsection{Evaluation of the Program}

The IDAS program is described to have become very popular, with between 70 and 100 women regularly participating in the activities in the program. About 50 women usually attended each meeting and seminar (Blom 2010). The success of the program is also highlighted in the fact that many of the women who participated subsequently attained senior academic leadership positions such as Dean, Pro-Rector, and Rector (Peterson 2010). The program has been described as "highly successful" and a "good example" of structural and institutional strategies (Bergman 2013, p. 34). The program has also been referred to as unique in Sweden. It was the only nationwide gender equality initiative targeting all Swedish higher education institutions (Heikkilä and Weinestål 2009; SOU 2011). Similarly, Agneta Blom explains that "[ $t$ ]he most significant aspect of the Swedish IDAS" was that it "became nationwide-eventually every university and college in Sweden was involved" (Blom 2010, p. 311).

\section{Results}

What follows below is the subjective experiences of women who participated in the IDAS program and their understanding of the importance of it, for them personally, but also for gender equality in Swedish higher education. In addition, and just as importantly, the results highlight how some of the women interviewed had chosen not to participate, and why they had made that decision.

\subsection{Women Accessing Authority through a Women-Only Leadership Development Program}

All women interviewed were asked how they would explain the increase of women in Rector position in the Swedish higher education sector since the beginning of the 2000s. When they tried to make sense of this increase, the single most important factor mentioned was the women-only leadership 
development program IDAS. When asked what they saw as the most important contributing factor to women's increase in the Rector position in Swedish higher education, they instantly mentioned IDAS, sometimes without being able to identify any other factor. More than half of the women explained that this had impacted the Swedish higher education and transformed the gender (im)balance on Rector level. Seven of the women expressed their appreciation of the IDAS project, echoing the following opinion: "I think that the IDAS program has been extremely important" (Rector 1). The program was seen as having achieved what it aimed to do, which was to increase women Rectors in Swedish higher education: "I believe that the IDAS project and networks like that are excellent efficient instruments to increase the number of women [in senior academic leadership positions]" (Rector 2). One of the women, as it turned out, had been part of the group that initially supported the program and helped to establish it. Most of the positive narratives about women-only leadership programs in general, and IDAS in particular, relied on the first approach/frame described above: The "fix the women"-approach or the "equip the woman"-frame (cf. Ely and Meyerson 2000b). The women produced these narratives as they made sense of the initiatives that, according to them, had empowered themselves and other women and strengthened their position in the organization by equipping them with appropriate skills, competence, and networks.

All of the women interviewed, except two, had participated in some way or another in the program and some of them, as we see below, explained that it had been of personal importance for them and described how it had supported them in their leadership career. The IDAS program managed to address one of the main explanations, or excuses, used to justify the lack of women Rectors; that there are no competent women candidates and/or that women do not put themselves forward as candidates. One of the women explained how the program had helped her to strive for leadership positions: "Encouragement and a form of mental preparation I think" (Rector 3). However, the interviews also highlighted that the program provided more indirect encouragement. The successful women who were invited to speak at IDAS events served as role models. The same Rector continued to explain: "And then that you get role models when you see what other people can and do. Then it's not that strange either [to be a woman and a Rector]. So I certainly think it's very positive" (Rector 3). This woman thus emphasized the importance of learning about women in senior academic leadership positions ("Then it's not that strange either"). The importance of meeting successful women and listening to them speak about their experiences and how they became academic leaders has been emphasized in the literature (Ely et al. 2011) and was also emphasized by other women: "It was great to hear the personal stories from the invited guests" (Rector 8). One of the women interviewed included not only the invited guests in the group of role models, but also the women participating in the meetings: "What was so much fun with IDAS was that you see how many really competent women there are. [laughter] How many we are" (Rector 12). She made an addition here by including herself in the group of "really competent women" ("How many we are"). She concluded with the consequences of this: "And you don't feel alone" (Rector 12). One of the women told how she had been part of one IDAS two-day meeting and how the conversations and exchange of experiences were helpful to her: "It was really fun. A lot of fun and exciting, to compare experiences and talk to colleagues, it was great fun" (Rector 11).

One of the most important aspects of the IDAS program was that the women participating in the meetings formed informal networks in which they could share information and experiences. The importance of such networks for women-only leadership programs has also been stressed in previous research (Bonebright et al. 2012; Ely et al. 2011; Peterson 2014). One of the women explained this as the "fun" part of IDAS: "You get a network of people that you know from IDAS. So that's fun" (Rector 12). Networking within IDAS was, however, not only "fun" but also highly "useful". One of the women told how she had participated in some of the activities that were part of the IDAS program, and she was asked about her opinion about it: "You get a network that you can use in different ways. That has absolutely helped me. No doubt about that" (Rector 3). Notwithstanding, women's networks have received criticism for not providing women with important information or access to power and positions in the same way as men's networks. Nevertheless, according to the women interviewed, 
the network with women in IDAS was not primarily a network to gain quick or immediate access to power. Instead, it was a support network and a network for learning and sharing information and experiences. The networks formed within IDAS were then perhaps more reminiscent of a "community of practice" than a career network. One of the women explained, in a little more detail, what these networks, formed with women in the IDAS program, provided: "You know that there are loads of women you can contact if you feel the need to discuss something" (Rector 12). This was also reflected in the account of the woman describing the two-day meeting she participated in and appreciated, when she explained exactly what it was that was important with the exchange with other women in IDAS: "We talked business: 'how do you deal with that?' So we discussed really very practical stuff too" (Rector 11).

In the accounts above, the women did not make sense of networks explicitly in relation to gender, power or gender (in)equality in academia. This relation was, however, explicit in other interviews. One of the Rectors emphasized the importance of networks and role models. She explained the benefits of participating in IDAS:

And then to form alliances with people there. Networks are always good. And I think, generally, I mean ... the male networks, they work pretty good and I actually believe that there is a need for women's networks. I think so. (Rector 8)

The woman here emphasized the importance of networks for her personally, but she also emphasized that networks are beneficial for women's leadership careers in a more general manner, as they could counteract the influential men's networks. Previous research has also highlighted how references to networks/lack of networks is a popular way of explaining and making sense of gender inequality in Swedish higher education (Göransson 2011). Another woman explained that she had a mentor and emphasized the importance of the fact that the mentor was a woman: "I would never ever dream about having a man as a mentor. Because I don't think they have the same experiences" (Rector 11). One of the women explained what she understood as the consequences of IDAS: "A lot has happened. It's not that remarkable anymore, to have a woman as Rector" (Rector 15). She, however, also emphasized the importance of women-only initiatives to support gender equality: "I think we have to continue with initiatives to support women because the problem won't just go away by itself. Things can easily go back to where they were before" (Rector 15).

There were, however, also more critical voices about IDAS among the women interviewed, as the next section demonstrates.

\subsection{Women Accessing Authority without Women-Only Leadership Programs}

Although praised by many of the women interviewed, there were also critical reflections regarding IDAS. One reason for paying specific attention to the critical reflections is that projects, measures, and activities that aim to promote gender equality often meet resistance. Strategies need to be developed concerning how to meet this resistance (Swedish Council for Higher Education UHR). Whether or not the critical reflections are actually expression of resistance or not is, however, not self-evident. Instead, there are nuances in the women's critical approaches, and some expressed ambivalence towards women-only initiatives; they both wanted to be supportive and raised their concerns.

One of the women suggested that the problem with IDAS and other women-only initiatives was that they instructed women to learn how to act like men. Instead, the woman argued, women leaders should be viewed as an important, and different, alternative to men leaders. The underlying assertion here was that women's difference from men, as a group, should be valued and praised. The woman interviewed stated her opinion regarding gender differences: "We [women and men] actually relate to our world in different ways. I think so" (Rector 4). According to this Rector, gender equality in academia involved that: "we should support women to be themselves as leader" (Rector 4). She continued to explain her view on the problem with women-only leadership development programs, which was based on courses that she had attended, among them IDAS: 
Women shouldn't become like men. We want women leaders because they in some way are different from men, don't we? But that is never given any attention. Instead we have to learn how to speak and those things are just silly! Every course I attend has an element where we are supposed to learn how to speak and how to breathe. Is this only included in courses for women? Is it possible that women already know how to talk and that it's men who should learn how to speak like women? I think it's absurd. We don't have to learn their behavior. Why don't men have to learn from women leaders? (Rector 4)

The way this woman made sense of gender, gender (in)equality in higher education leadership, and women-only leadership development initiatives could be interpreted within the model developed by Ely and Meyerson (2000b). According to this model, the woman's sense-making involved criticizing and refuting the first approach, "fix the woman" or "equip the woman", while at the same time making a case for the second approach, the "value the feminine" approach (Ely and Meyerson 2000b).

Another kind of criticism, voiced by several of the women, addressed the tendency of women-only initiatives to essentialize women and portraying them as a homogeneous group. This type of criticism made sense of gender, gender (in)equality in higher education leadership, and women-only leadership development initiatives in opposition to the "value the feminine" approach. One of the women was asked whether she had taken part in any women-only leadership initiatives, and she explained that she had taken part in a couple of IDAS meetings, without really "actively participating" (Rector 5):

I just haven't really felt much of a need for it. And I haven't felt that I belong there. Not all women feel at home in IDAS. I have never felt at home in these types of IDAS networks. Women are different. And it's important not always having to feel like you are one of the women. (Rector 5)

This criticism could be interpreted as based on experiences of being a token woman in male-dominated situations in academia (Peterson 2014). This woman's experiences were thus diametrically distinct from the ones described by other women, who associated IDAS with inclusion, recognition, understanding, and sharing between women in similar situations and with similar experiences.

Other women raised their concerns about the content of the leadership development courses. One of the other women was asked whether she had taken part in any women-only initiatives, and she told about how she had perceived that the IDAS course she had participated in "was a little too much focused on being a woman rather than being a leader" (Rector 7). According to her, that meant that the course dealt with how women traditionally had been subordinated in the university system. Instead, she would have preferred if the focus had been on "efficient leadership" and on "practical advice on how to deal with certain situations" (Rector 7). Another woman similarly criticized women-only leadership development programs such as IDAS: "they lack substance and it becomes ... ridiculous" (Rector 14). She instead wished for "a whole other mentality". Although this woman did not expound on exactly what it was she found "ridiculous", another woman told a longer story that echoed a similar attitude. She depicted how she attended a two-day IDAS meeting where women were taught how to deal with men using master suppressing techniques (e.g., objectifying, ridicule, make invisible):

I told the teacher how I would deal with being snubbed. I would insist on being heard and get my answer and then ask the man to leave. I'm not putting any more energy into such a situation. But this teacher told me that I used the wrong strategy. Instead, I was supposed to gain power by putting my purse down and arranging the curtains. It was just really bizarre. I looked at the teacher and asked "do you really think I have the energy and time to play these silly games?". (Rector 9)

According to her, instead of focusing on these "silly games", the real problem was lack of transparency when positions were filled and "men's networks and collegiality" (Rector 9). 
The women also voiced a type of criticism that could be categorized as drawing on the fourth approach/frame in the model developed by Ely and Meyerson (2000b); "post equity". This approach involves resisting and revising the dominant discourse, developing new organizational narratives, and changing the organizational culture. One of the women similarly argued for a new conceptualization of academic leadership, beyond "women' leadership":

I think that the IDAS program, and other initiatives, have been extremely important, but I think it's time to start thinking in new ways. We can't just talk about women's leadership but instead about an inclusive leadership where we include different aspects. How can we make leadership attractive to people in the future? We don't want leaders who just want to climb the career ladder, do we? (Rector 10)

Other women also voiced their criticism of the emphasis on career in IDAS. One of the women interviewed explained that IDAS had encouraged a single-minded, careerist view and had supported: "careerist that are applying for every position as Rector out there, just because they want to become Rector" (Rector 14). Another woman criticized a lecture in IDAS where a former Rector "talked about how much fun it is to have power" (Rector 6). This type of criticism is based on arguments about what should motivate academic senior leaders: "I enjoy power but I enjoy having influence over things that interest me. I enjoy having an idea and being able to execute it" (Rector 6). This could be interpreted in relation to previous research that has highlighted the importance of role modelling for women and that women leaders are more effective as role models "when they do not adopt a tough, aggressive masculine stance" (Bagilhole and White 2011, p. 201).

\section{Discussion}

As we have seen, there were a multitude of different ways of making sense of a women-only leadership development initiative. The women expressed an array of different experiences. The analysis shows that some participants attributed part of their success to program participation, largely through networking, peer coaching, and role modeling. Eight of them expressed their enjoyment in participating and fully supported the initiative. These women's different narratives were analyzed and discussed in relation to the four different approaches to conceptualize gender and address problem of gender inequity (cf. Ely and Meyerson 2000b). Several of the sense-making narratives can be understood as framing gender and gender inequality within the first approach described by Ely and Meyerson (2000b), which focuses on providing women with resources to compete with men. Initiatives shaped by this approach rarely lead to positive changes of a more substantial kind and have therefore been deemed as generally ineffective. The narratives could, however, also be interpreted as if IDAS created a platform for the women from which to actually start a transformation. According to the women, the IDAS program had contributed to empowering individual women, encouraging them and providing them with the resources they needed to put forth themselves as candidates for Rector positions. They also emphasized that the program had transformed the gender balance of senior academic leadership in Swedish higher education and thus contributed to institutional and structural change.

Previous research has highlighted how university management is viewed as a hostile environment for women (Bagilhole and White 2011). The women's narratives about how IDAS supported and encouraged them can be interpreted as reflecting male domination in their working environment and the masculine academic culture which made them feel like they were intruders and tokens; that they were excluded and that they did not quite belong (cf. O'Connor and Göransson 2015). The initiatives within the IDAS program counteracted this and created an important arena where women experienced belonging and inclusion. The interviews, however, also show that some women do not feel at home in women-only leadership development programs.

Seven of the 15 women interviewed were more ambivalent, expressing their criticism regarding certain aspects of the women-only program and some even dissociating themselves from initiatives 
like this. The results suggest that they did not participate fully in the IDAS program. These women's experiences of the IDAS program, however, are important to acknowledge as they reflect common examples of challenges and dilemmas with women-only programs. Women do not like to feel that they are "helped" by programs but that they are empowered, and that they are empowered not (only) as women but as competent and accomplished leaders (Van den Brink and Stobbe 2014).

The results provide support to previous research that has studied women-only leadership development programs through a lens of social and gender identity, with the program sometimes producing conflicting identity positions (cf. Ely et al. 2011; De Vries 2010). When these women made sense of the women-only leadership development program IDAS, they were also involved in identity work. Their sense-making of the program was related to their self-identities as leaders and their identity-construction as women senior leaders in academia. This could account for the very different sense-making strategies the women used, both the criticism voiced and the support for certain aspects of the program, perhaps especially the networking aspects. As Ely, Ibarra, and Kolb (Ely et al. 2011, p. 478) explain: "If constructing a leader identity is a fundamentally relational endeavor, then people's informal networks should play a key role in the process of becoming a leader".

Some of the criticism voiced by the women could be interpreted in relation to the distinction between training and development, which De Vries (2010) emphasizes. According to de Vries, training fits the "fix the women" frame and has a fixed and regulated agenda with right and wrong answers. Interventions focusing on women's development, on the other hand, start from the individual woman's need and the issues she wants to address, thus fitting better with her "identity work".

Ely and Meyerson (2000b, p. 107) categorize "leadership development courses that focus on helping women develop the skills and styles considered requisite for successes" as examples of the first approach, "fix the women". They, however, also emphasize that the four approaches to gender and gender equality initiatives are not mutually exclusive but rather overlap and sometimes are mixed together (Ely and Meyerson 2000b). Bonebright, Cottledge, and Lonnquist (Bonebright et al. 2012) also describe guiding principles for building leadership development programs for women using guidelines that both honors women's leadership style (approach 2) and leads to equity and systems change (approach 4). Perhaps it is important for those interested in setting up women-only programs to make sure to be explicit about which approaches are included-and perhaps also make sure to include several of the approaches, combining them to attract women and to make them as efficient as possible?

Over the years, a number of initiatives aiming to strengthen specifically gender in research policies as well as initiatives for increasing gender equality within research in Sweden have been implemented. As in many other countries, the focus has shifted from "women as the problem" to addressing structures, organizations, culture, and leadership within higher education institutions that contribute to reproducing gender inequalities and gender imbalance (cf., e.g., Bergman 2013; Burkinshaw 2015). IDAS can be viewed as a program that contributed to facilitating such a shift. Although many similar programs have been criticized for a "fixing the women" approach (cf. Ely and Meyerson 2000a; Meyerson and Kolb 2000), the IDAS program attempted to introduce a more sustainable and long-term transformation of institutional and structural character.

What did the IDAS program change and what type of gender transformation did it contribute to? Based on the interviews with the women Rectors, the program contributed in several different ways. It supported women in applying for senior academic leadership positions. It also contributed to changing the leadership ideal. It drew attention to the fact that the leadership ideal was shaped by men and hegemonic masculinity. Most importantly, it also drew attention to women as competent leaders, and to women being asked, nominated, and appointed to these positions to a higher degree.

Funding: This research was funded by the Swedish Research Council for Health, Working Life and Welfare, grant number 2012-01159.

Conflicts of Interest: The author declares no conflict of interest. 


\section{References}

Acker, Joan. 1990. Hierarchies, jobs, bodies: A Theory of Gendered Organizations. Gender and Society 4: 139-58. [CrossRef]

Acker, Joan. 2000. Gendered Contradictions in Organizational Equity Projects. Organization 7: 625-32. [CrossRef]

Acker, Joan. 2006. Inequalities Regimes: Gender, Class, and Race in Organizations. Gender and Society 20: 441-64. [CrossRef]

Acker, Joan. 2012. Gendered organizations and intersectionality: Problems and possibilities. Equality, Diversity and Inclusion: An International Journal 31: 214-24.

Bagilhole, Barbara, and Kate White. 2011. Towards interventions for senior women. In Gender, Power and Management. A Cross-Cultural Analysis of Higher Education. Edited by Barbara Bagilhole and Kate White. Basingstoke: Palgrave Macmillan.

Barnard, Sarah, John Arnold, Sara Bosley, and Fehmidah Munir. 2016. Onwards and Upwards? Tracking Women's Work Experiences in Higher Education. Year 1 report. Leadership Foundation for Higher Education. Loughborough: Loughborough University.

Bergman, Solveig. 2013. The Nordic Region-A Step Closer to Gender Balance in Research? Joint Nordic Strategies and Measures to Promote Gender Balance among Researchers in Academia. TemaNord 2013:544. Copenhagen: Nordic Council of Ministers.

Blom, Agneta. 2010. IDAS: A program to increase the number of women leaders in Swedish higher education. In Leadership through the Gender Lens. Women and Men in Organisations. Research Reports 71. Edited by Liisa Husu, Jeff Hearn, Anna-Maija Lämsä and Sinikka Vanhala. Helsinki: Hanken School of Economics, pp. 305-12.

Bonebright, Denise A., Anitra D. Cottledge, and Peg Lonnquist. 2012. Developing Women Leaders on Campus: A Human Resources-Women's Center Partnership at the University of Minnesota. Advances in Developing Human Resources 14: 79-95. [CrossRef]

Burkinshaw, Paula. 2015. Higher Education, Leadership and Women Vice Chancellors: Fitting in to Communities of Practice of Masculinities. New York: Springer.

Corby, Michelle E. 2014. Administrative Fellows Experiences in Achieving Leadership Development Goals via Participation in a University Sponsored Program. Ph.D. thesis, Pennsylvania State University, University Park, PA, USA.

Dahlerup, Drude. 2010. Jämställdhet i akademin. En forskningsöversikt. Stockholm: Delegationen för jämställdhet i högskolan.

De Vries, Jennifer. 2010. A Realistic Agenda? Women Only Programs as Strategic Interventions for Building Gender Equitable Workplaces. Ph.D. thesis, University of Western Australia, Crawley, Australia, December 10.

Doherty, Liz, and Simonetta Manfredi. 2010. Improving women's representation in senior positions in universities. Employee Relations 32: 138-55. [CrossRef]

Elo, Satu, Maria Kääriäinen, Outi Kanste, Tarja Pölkki, Kati Utriainen, and Helvi Kyngäs. 2014. Qualitative Content Analysis: A Focus on Trustworthiness. SAGE Open 4: 1-10. [CrossRef]

Ely, Robin J., and Debra E. Meyerson. 2000a. Advancing gender equity in organizations: The challenge and importance of maintaining a gender narrative. Organization 7: 589-608. [CrossRef]

Ely, Robin J., and Debra E. Meyerson. 2000b. Theories of gender in organizations: A new approach to organizational analysis and change. Research in Organizational Behaviour 22: 103-51. [CrossRef]

Ely, Robin J., Herminia Ibarra, and Deborah M. Kolb. 2011. Taking gender into account: Theory and Design for Women's Leadership Development Programs. Academy of Management Learning \& Education 10: 474-93.

European Commission. 2019. She Figures 2018. Statistics and Indicators on Gender Equality in Science. Luxembourg: Office for Official Publications of the European Communities.

Fahlgren, Margaretha, Kerstin Norén, and Birgitta Sandström. 2007. Akademiskt ledarskap nu och i framtiden. Fokus på rektorsrekrytering. Report from the IDAS Program. Växjö: IDAS.

Göransson, Anita. 2011. Gender Equality and the Shift from Collegiality to Managerialism. In Gender, Power and Management. A Cross-Cultural Analysis of Higher Education. Edited by Barbara Bagilhole and Kate White. Basingstoke: Palgrave Macmillan.

Heikkilä, Mia, and Annelie Häyrén Weinestål. 2009. Kartläggning och analys av jämställdhetsinsatser vid svenska lärosäten 2000-2009. Stockholm: Delegationen för jämställdhet i högskolan. 
Hsieh, Hsiu-Fang, and Sarah E. Shannon. 2005. Three Approaches to Qualitative Content Analysis. Qualitative Health Research 15: 1277-88. [CrossRef]

IDAS. 2007a. Att leda in akademisk miljö år 2020. Om forskningsfinansiering ur olika perspektiv. Ett idéseminarium inom IDAS-projektet, 2007. Report from the IDAS Project. Växjö: IDAS.

IDAS. 2007b. Ögonblicksbilder om IDAS. Utifrån KP-ars perspektiv våren 2007. Report from the IDAS Program. Växjö: IDAS.

Krippendorff, Klaus. 2013. Content Analysis: An Introduction to Its Methodology. London: Sage.

Ljung, Kerstin Lannerlöv. 2005. Rektor på 20 sätt. Personliga reflektioner om hur det är att leda universitet och högskolor. Report from the IDAS Project. Växjö: IDAS.

Madsen, Susan R., Karen A. Longman, and Jessica R. Daniels. 2012. Women's leadership development in higher education: Conclusion and implications for HRD. Advances in Developing Human Resources 14: 113-28. [CrossRef]

Magrane, Diane, and Page S. Morahan. 2016. Fortifying the Pipeline to Leadership: The International Center for Executive Leadership in Academics at Drexel. In Forward to Professorship in STEM. Cambridge: Academic Press, pp. 319-36.

Manning, Jimmie, and Adrianne Kunkel. 2014. Making meaning of meaning-making research: Using qualitative research for studies of social and personal relationships. Journal of Social and Personal Relationships 31: 433-11. [CrossRef]

Marcusson, Lena. 2007. Det akademiska ledarskapet. Några europeiska perspektiv. Report from the IDAS Program. Växjö: IDAS.

McLellan, Eleanor, Kathleen MacQueen, and Judith Neidig. 2003. Beyond the Qualitative Interview: Data Preparation and Transcription. Field Methods 15: 63-84. [CrossRef]

Meyerson, Debra E., and Deborah M. Kolb. 2000. Moving out of the 'armchair': Developing a framework to bridge the gap between feminist theory and practice. Organization 7: 553-71. [CrossRef]

Morley, Louise. 2013. The rules of the game: Women and the leaderist turn in higher education. Gender and Education 25: 116-31. [CrossRef]

Nydahl, Erika. 2007. Utan en obstinat gen hade jag aldrig försökt. Intervjuer med 62 framgångsrika kvinnor inom universitet och högskola. En intervjuundersökning inom IDAS-projektet. Växjö: IDAS.

O'Connor, Pat, and Anita Göransson. 2015. Constructing or rejecting the notion of the other in university management: The cases of Ireland and Sweden. Educational Management Administration E Leadership 43: 323-40.

O'Meara, KerryAnn, and Nelly P. Stromquist. 2015. Faculty peer networks: Role and relevance in advancing agency and gender equity. Gender and Education 27: 338-58. [CrossRef]

Parr, Sadie. 2015. Integrating critical realist and feminist methodologies: Ethical and analytical dilemmas. International Journal of Social Research Methodology 18: 193-207. [CrossRef]

Peterson, Helen. 2010. Akademiskt ledarskap i balans? Kvinnor på ledande positioner vid svenska universitet och högskolor 1990-2010. En rapport från IDAS-projektet. [Academic Management in Balance? Women in Senior Management Positions in Swedish Higher Education 1990-2010]. Studies in Technology and Social Change, report no. 49. Linköping: Linköpings Universitet.

Peterson, Helen. 2014. 'Someone needs to be first.' Women Pioneers as Change Agents in Higher Education Management. In Gender Transformations in the Academy: Advances in Gender Research. Edited by Marcia Texler Segal, Visilikie Demos and Catherine White Berheide. Bingley: Emerald Books, vol. 19, pp. 395-413.

Peterson, Helen. 2015. Exit the King, Enter the Maid: Changing Discourses on Gendered Management ideals in Swedish Higher Education. Gender in Management: An International Journal 30: 343-57. [CrossRef]

Peterson, Helen. 2016. Is Managing Academics 'Women's Work'? Exploring the Existence of a Glass Cliff in Higher Education Management. Educational Management Administration and Leadership 44: 112-27. [CrossRef]

Peterson, Helen. 2017. Gender and prestige in Swedish Academia: Exploring senior management in universities and university colleges. Scandinavian Journal of Educational Research 61: 1-17. [CrossRef]

Peterson, Helen. 2018. From "Goal-Orientated, Strong and Decisive Leader" to "Collaborative and Communicative Listener". Gendered Shifts in Vice-Chancellor Ideals, 1990-2018. Education Sciences 8: 90. [CrossRef]

Ryan, Gery W., and H. Russell Bernard. 2003. Techniques to Identify Themes. Field Methods 15: 85-109. [CrossRef] Scheibelhofer, Elisabeth. 2007. Combining Narration-Based Interviews with Topical Interviews: Methodological Reflections on Research Practices. International Journal of Social Research Methodology 11: 403-16. [CrossRef] 
Seidman, Irving. 1998. Interviewing as Qualitative Research. New York: Teachers College Press.

Smith, Jonathan A., Maria Jarman, and Mike Osborn. 1999. Doing interpretative phenomenological analysis. In Qualitative Health Psychology: Theories and Methods. Edited by Michael Murray and Kerry Chamberlain. London: Sage, pp. 218-40.

SOU. 2011. Svart på vitt—om jämställdhet i akademin. Slutbetänkande från Delegationen för jämställdhet i högskolan. Stockholm: Fritzes.

Swedish Council for Higher Education (UHR). 2014. Jämställdhet i högskolan-Ska den ordnas en gång för alla? [Equality in Higher Education-Once and for all?]. Stockholm: Swedish Council for Higher Education (UHR).

Swedish Research Council. 2006. IDAS utvecklar kvinnor som vill bli ledare. In Forskning E Medicin. Stockholm: Vetenskapsrådet.

Swedish Research Council. 2017. Good Research Practice. VR1710. Stockholm: Swedish Research Council.

Van den Brink, Marieke, and Lineke Stobbe. 2014. The support paradox: Overcoming dilemmas in gender equality programs. Scandinavian Journal of Management 30: 163-74. [CrossRef]

White, Judith S. 2012. HERS institutes: Curriculum for advancing women leaders in higher education. Advances in Developing Human Resources 14: 11-27. [CrossRef]

(C) 2019 by the author. Licensee MDPI, Basel, Switzerland. This article is an open access article distributed under the terms and conditions of the Creative Commons Attribution (CC BY) license (http://creativecommons.org/licenses/by/4.0/). 